\title{
Laryngeal Mask Insertion Using a Laryngoscope: Description of Technique
}

\author{
Ali Shahriari* \\ Department of anesthesiology and clinical care; Roozbeh Hospital \& Tehran University of Medical Sciences, Iran
}

Submission: February 01, 2019; Published: February 15, 2019

*Corresponding author: Ali Shahriari, Department of anesthesiology and clinical care; Roozbeh Hospital; Tehran University of Medical Sciences: Tehran, Iran

Keywords: Anesthesiologist; Endotracheal intubation; Chest expansion; Incisors; Tongue

\section{Commentary}

Appropriate airway management is an important mission for the anesthesiologist. However endotracheal intubation remains the gold standard for the airway management, this maneuver can be difficult or impossible in some circumstances [1].

Incorrect insertion of the laryngeal mask airway (LMA) can lead to pneumonia aspiration, and airway obstruction [2]. Correct airway insertion is confirmed when there is no air leak during ventilation and the patient has an acceptable chest expansion during ventilation and normal airway pressure. To date, multiple methods have been proposed for the placement of LMA such as classic [3], reverse classic, inflated cuff methods [4]. Fatemeh Roodneshin \& Mahvash Agah [5] presented a method: the index finger of the left hand must be placed on the tongue pushing it downwards (towards the floor of the mouth) when inserting the LMA

Goyal et al. [6] proposed two methods of insertion of LMA: In one method: the laryngeal mask airway must be inserted from the head end of the patient when the cuff is partially inflated, the posterior surface of the cuff must be lubricated with. The patient's head was supported on a firm ring with neck flexed and head extended. The tube portion of the laryngeal mask was grasped as if it were a pen; the index finger was pressed on the point where the tube adjoins the mask. The patient's mouth was opened; the tip of the mask was placed against the inner surface of the upper incisors or gums with the aperture facing anteriorly (and the black line facing the patient's upper lip). The mask was pressed back against the hard palate to keep it flattened as it advanced into the hypopharynx, using the index finger to push upward against the palate. The tube was grasped with the other hand, straightened slightly, and then pressed down with a single, quick but gentle movement until a definite resistance was felt [7].

In other group, the LMA was inserted from the right side of the patient, i.e. the operator stood facing the patient, in the angle made by the chest and right arm of the patient. After partially inflating the cuff (i.e. filled with half the recommended air in the cuff), the posterior surface of the cuff was lubricated with water-soluble jelly. The patient's head was supported on a firm ring with neck flexed and head extended. The tube portion of the laryngeal mask must be grasped in a pen-like fashion; the mask must be pressed by the thumb. After opening the patient's mouth, the tip of the mask was placed against the inner surface of the upper incisors with the aperture facing anteriorly. The mask must be pressed against the hard palate must be pushed into the pharynx until a major resistance was felt. In this technique, the thumb was used to apply pressure against the hard palate while advancing the LMA [8].

The method that we proposed is using a laryngoscope for LMA insertion: At first step, the anesthesiologist opens the patient's mouth, the head must be extended. Holding a laryngoscope in the left hand, he inserts it into the mouth of the patient with the blade directed to the right part of the mouth. Once the right tonsil is reached, the laryngoscope is swept to the midline, keeping the tongue on the left part of the mouth, to bring the epiglottis into view. Next, the laryngoscope is forced upwards, and in this step the anesthesiologist takes the LMA in the right hand and starts inserting it through the mouth opening.

\section{References}

1. European Resuscitation Council (ERC), American Heart Association (AHA), International Liaison Committee on Resuscitation (ILCOR) 
(2000) International Guidelines 2000 for Cardiopulmonary Resuscitation and Emergency Cardiac Care 6.

2. Tabari M, Alipour M, Ahmadi M (2013) Hemodynamic changes occurring with tracheal intubation by direct laryngoscopy compared with intubating laryngeal mask airway in adults: A randomized comparison trial. Egypt J Anaesth 29(2): 103-107.

3. Brain A (1990) Proper technique for insertion of the Laryngeal Mask. Anesthesiology 73(5): 1053-1054.

4. Haynes SR, Morton NS (1993) The laryngeal mask airway: A review of its use in Pediatric Anesthesia. Pediatr Anaesth 3(2): 65-73.
5. Roodneshin F, Agah M (2011) Novel Technique for Placement of Laryngeal Mask Airway in Difficult Pediatric Airways. Tanaffos 10(2): 56-68.

6. Goyal M, Dutt A, Khan Joad AS (2013) Laryngeal mask airway insertion by classic and thumb insertion technique: a comparison. F1000Res 2: 123.

7. Matta BF, Marsh DS, Nevin M (1995) Laryngeal mask airway: A more successful method of insertion. J Clin Anesth 7(2): 132-135.

8. Rashid MK, Bhatti TH, Moeid SA (2005) Laryngeal mask airway and the difficult airway management. J Anaesth Clin Pharmacol 21(3): 241246.

\begin{tabular}{l} 
Your next submission with Juniper Publishers \\
will reach you the below assets \\
- Quality Editorial service \\
- Swift Peer Review \\
- Reprints availability \\
- E-prints Service \\
- Manuscript Podcast for convenient understanding \\
- Global attainment for your research \\
- Manuscript accessibility in different formats \\
( Pdf, E-pub, Full Text, Audio) \\
- Unceasing customer service \\
Track the below URL for one-step submission \\
https://juniperpublishers.com/online-submission.php \\
\hline
\end{tabular}

